UDC 347.626-055.2(497.11:450)"18"

CERIF: S130, H240, H300

DOI: 10.51204/HLH_20205A

\title{
Андреј ЦОНФАЛОНИЕРИ
}

\section{ПОРЕЂЕЊЕ ПРАВНОГ ПОЛОЖАЈА ЖЕНА У БРАКУ И НАСЛЕЂИВАҢУ У СРПСКОМ ГРАЂАНСКОМ ЗАКОНИКУ ИЗ 1844. И ГРАБАНСКОМ ЗАКОНИКУ КРАЉЕВИНЕ ИТАЛИЈЕ ИЗ 1865.}

Раg се бави уйоредном анализом ӣравноі йоложаја жена у Срӣском ірађанском законику (1844) и у Грађанском законику Кральевине Ийалије (1865) у йоілеgу норми које реїулишу йоложај жене у браку и оних у којима се іовори о наслеђивағу. Иако је сам сииил йисана норми gруїачиј, ӣримећује се оgређена сличности у оgреgбама о браку, о нносима суйружника, односима суйружни-

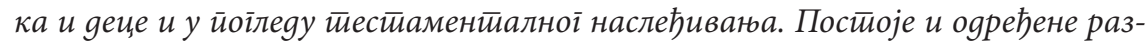
лике које су, у већем делу, занемарливе. Највећа разлика јесте начин на који је реіуллисано законско наслеђиване: яок је у ийалијанском иризнатио ирраво на наслеђиване брачној gеци без обзира на йол, у срйском су жене искључене из наслеgстива. Разлика се оілеgа и у йоме шито се иррельба сматира разлоіом за сейарацију у Ийалијанском законику само у случају gа је учини жена, gок у Срйском није йрецизиран йол иррељубника као моїући разлоі за развоg брака. Срйски законодаваи, уређује и йоложај жене у заярузи, gок итиалијански не

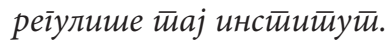

Кључне речи: Положај жене. - Срӣски ірађански законик. - Грађански законик Кралевине Ийалије. - Брак. - Законско наслеђиване.

Аутор је студент треће године на основним академским студијама на Правном факултету Универзитета у Београду, andrej.confalonieri@gmail.com 


\section{1. УВОД}

Када помислимо да је у двадесет првом веку могуће некога дискриминисати само на основу припадности супротном полу, ${ }^{1}$ јасно је због чега је релевантно проучавати разлоге који су довели до тога да се жена сматра инфериорном у односу на мушкарца, као и саме правне системе у којима се налазе дискриминаторске норме. Ови разлози се јављају на самом почетку људске цивилизације. Још од давнина је жена сматрана бићем ниже вредности у односу на мушкарца. ${ }^{2}$ Иако Ева Кантарела (Eva Cantarella) наводи да су узрок томе пре свега били културолошки разлози, а касније и чињеница да се сматрало да по природи ствари жена мање вреди, ${ }^{3}$ сматрамо да је њена потчињеност у старим друштвима настала из биолошког разлога - мањка

1 Примера ради, према истраживању које је спровео Републички завод за статистику Србије 2012. године, жене у Србији зарађују мање од мушкараца јер су њихови послови мање плаћени, а често су чак и за исти посао плаћене мање. Такође, имају мање изгледе да напредују у каријери, и добијају лошије послове. Оне су више оптерећене од мушкараца у кућним пословима, па просечна жена у Србији 2012. троши преко 4 сата на неплаћени рад, док просечни мушкарац мало преко сат и по. Мушкарци су бројнији на утицајним пословима, па има мање жена међу директорима, председницима, премијерима итд. Жене су такође жртве сексуалног и родно засниваног насиља које произилази из структурне неједнакости мушкарца и жене, што значи да, иако се женин положај знатно поправио у последњих неколико деценија, и даље постоје многи проблеми које треба решити у том погледу, како у Србији, тако и у иностранству. Дискриминације на основу пола је могуће уочити и у иностранству, нпр. у одређеним азијским државама, у којима се могу пронаћи закони о раду и о својини који праве полне дискриминације или норме којима није предвиђено кажњавање насиља над женама. Чак је и у Србији насиље у породици инкриминисано као кривично дело тек 2002. године, иако оно као такво пружа заштиту породици у целини, посредно штитећи и жене. Joshua Eastin, „Aseem Prakash, Economic Development and Gender Equality: Is There a Gender Kuznets Curve?", World Politics 65(1), 2013, 162; Милован М. Митровић, Данило С. Вуковић, Основи соииолоіије йрава, Правни факултет Универзитета у Београду, Београд 2018, 91-93; Наташа Делић, „Кривично дело насиља у породици (члан 194. КЗС): законски појам, доктринарни ставови и судска пракса", Лепосава Крон (ур.), Нaсилнички криминал: етииолоіија, феноменолоїија, ирревениија, 2010, 92.

2 Што је контрадикторно ако се посматра чињеиица да су многи песници величали жену у својим песмама (раније), а поготово апсурд представља чињеница да је жена у хришћанству „узвишена на највиши степен моралне вредности, до самог божанства”, а са друге стране је „бачена у кал до узрочнице свега зла и сваке несреће у свету". Вид. Фердо Чулиновић, Жена у нашем кривичном йраву, Глобус, Београд 1934, 11 и даље.

3 Она наводи да се социјална организација римске државе и грчких држава може сматрати тренутком када је разлика између полова кодификована, па су њу људи почели да схватају као биолошку разлику која означава инфериорност жене у односу на мушкарца, а престали су на њу да гледају као на културал- 
физичке снаге у односу на мушкарца у друштвима која су почивала искључиво на физичком раду, ${ }^{4}$ а да се та потчињеност задржала до данашњих дана.

Иако се временом положај жене побољшао, ${ }^{5}$ и данас се наилази на велике проблеме. Највећи од њих свакако јесте вековима усађена свест о својеврсној власти коју муж има над женом и немогућност жене да преко сопственог положаја у друштву оствари себе као личност. Управо зато, превазилажење ове препреке треба посматрати као процес који се постепено одвија, узимајући у обзир и чињеницу да се положај у коме се жене налазе врло разликује у зависности од ситуације али и дела света о ком говоримо, јер се положај жене „тешко може посматрати изоловано од положаја и живота читавог становништва, од проблема права човека уопште, од друштвене структуре, економског и политичког система, и, разуме се, од самог нивоа развитка уопште: привредног, техничког и културног; од улоге религије, од обичаја". ${ }^{6}$

Како је време пролазило и како се мењала и развијала привреда, највише услед индустријске револуције која се догодила у другој половини деветнаестог века, све више жена је видело могућност самоостварења у радном ангажовању које се слободно може сматрати једним од првих већих корака у борби за побољшање њиховог положаја, која траје вековима. „То је моменат, када су први пут жене у масама изашле из тесног фамилијарног круга на рад ван куће. Живот се показао јачи од канонских прописа, који забрањују женама свако занимање ван домаћинског круга". Узимајући у обзир чињеницу да се положај жене сам по себи тешко може посматрати изоловано од положаја и живота читавог становништва, долазимо до закључка да су промене биле неминовне на готово сваком плану друштвеног развитка и слободе. Француска револуција, која је поникла на управо

ну разлику. Eva Cantarella, Lambiguo malanno: condizione e immagine della donna nell'antichità greca e romana, Feltrinelli Editore, Milano 2010, 4 и даље.

4 Сматрамо да би било примереније рећи да су каснији културолошки разлози надградња, али не и основни разлог правне потчињености жена.

5 О дискриминацији жена и постепеном развоју жениних права кроз историју вид. исцрпно нпр: Bonnie G. Smith, The Oxford Encyclopedia of Women in World History, Volume 1, Oxford University Press, London 2008, xxviii-cxxxvii; E. Cantarella, 1 и даље; Linda L. Clark, Linda Loeb Clark, Women and Achievement in Nineteenth-Century Europe, Cambridge University Press, Cambridge 2008, 5 и даље; Elise Boulding, The Underside of History: A View of Women Through Time, Westview Press, Boulder 1977.

6 Митра Митровић, Положај жене у савременом свеш̄y, Народна књига, Београд 1960, 7.

7 Ана Божић, Положај жене у йривайном йраву: кроз истиорију gо gанас, Београд 1939, 199-200. 
оваквим идејама, није нарочито успешно решила питање положаја жене, ${ }^{8}$ али свакако чињеница остаје да су „те велике идеје прешле границе Француске и великим таласима плавиле околне државе, нарочито Енглеску, Скандинавске државе и Немачку и придонеле да се у тим земљама правни положај жене рапидно поправи". 9 То је и период доношења првих грађанских законика који су се, неки у мањој, неки у већој мери, бавили и овим питањем. Међу њима се налазе и Законик грађански за Књажество србско (који се у литератури чешће среће под називом Српски грађански законик, због чега ћемо у даљем тексту употребљавати скраћеницу СГЗ) и Грађански законик Краљевине Италије (Codice civile del Regno d'Italia, даље ИГЗ).

Постоји више разлога који оправдавају проучавање и поређење ова два законика. Пре свега, разлог се налази у чињеници да се у српској литератури нико још увек није бавио упоредном анализом положаја жена у ова два законика, управо због тога што се највећи број писаца бави анализом Француског грађанског законика (Code civil des Français или Code Napoléon, даље ФГЗ) из 1804. и Аустријског грађанског законика (Allgemeines Bürgerliches Gesetzbuch, даље АГЗ) из 1811 , који су несумњиво имали утицаја на велики број грађанских кодификација у Европи. Даље, могу се поредити са историјског аспекта њиховог доношења, у том смислу што је СГЗ донет неколико година након што се српска држава ослободила турске власти, а италијански неколико година након унификације из 1861. Треће, СГЗ и ИГЗ имају различите узоре. СГЗ је примарно писан на основу АГЗ-а, а ИГЗ по узору на ФГЗ. ${ }^{10}$ Ипак, и један и други законик имају брач-

8 Војислав Станимировић каже да је „велика француска револуција мимоишла жене” и да се, „између осталог, под утицајем Наполеона, о жене теже огрешио први модерни законик Европе, Code civil”. Војислав Станимировић, „Снага обичаја - породица у српском грађанском законику између старог и новог”, Милена Полојац, Зоран С. Мирковић, Марко Ђурђевић (ур.), Срйски ірађански законик - 170 іодина (СГЗ - 170), Правни факултет Универзитета у Београду, 2014, 156.

9 А. Божић, 199-200.

10 Иако су многи сматрали да је аустријска кодификација боља од француске, постојали су политички разлози који су довели до одбацивања њеног законодавства. Наиме, средином XIX века су Аустрија и тадашње Краљевство Сардинија водили више ратова, па се онда поставља питање могућности приклањања „веома католичкој Аустрији и њеном законодавству, када је баш Аустрија најгорчи непријатељ новонастале унитарне државе” („соте ci si può richiamare alla „cattolicissima” Austria e alla sua legislazione, quando è proprio l'Austria il più acerrimo nemico del nascente stato unitario?"). Исто тако, између 1828. и 1837. нацрт будуће српске грађанске кодификације рађен је по узору на Наполеонов кодекс, уз извесне модификације, а не по узору на АГЗ, што је имало утицаја на неке разлике између СГЗ-а и АГЗ-а. Giulia Galeotti, „Lautorizzazione maritale nel primo codice civile unitario: un istituto „estraneo” alla 
ноправна и наследноправна решења различита од оних садржаних у њиховим узорима (нпр. у СГЗ су унете норме и из ФГЗ-а). ${ }^{11}$ Тако, са једне стране СГЗ се највише разликује од АГЗ-а у погледу законског наслеђивања. Са друге стране, и ИГЗ има неколико разлика у односу на ФГЗ: пре свега, укинут је институт "fente successorale", ${ }^{12}$ постоји разлика у погледу положаја полубраће и преживелог супружника, а и законско наслеђивање је регулисано на другачији начин. ${ }^{13}$ Коначно, умесно је поређење на основу конзервативности двају законика у погледу положаја жене, јер је СГЗ у том погледу конзервативнији од свог изворника, а узор ИГЗ-а је врло конзервативни ФГЗ.

Узевши у обзир све специфичности, али и бројне сличности које постоје између СГЗ-а и ИГЗ-а, сматрамо да је њихово поређење релевантно како са правног аспекта, тако и са историјског аспекта њиховог доношења.

\section{2. ПОРЕЂЕЊЕ ПОЈЕДИНИХ ИНСТИТУТА У ПОГЛЕДУ ПОЛОЖАЈА ЖЕНЕ У СГЗ-У И ИГЗ-У}

Неједнакости између жене и мушкарца се могу видети и при површном посматрању како једног, тако и другог грађанског законика.

tradizione italiana?", Dimensioni e problemi della ricerca storica 2/2005, 162. Sima Avramović, „The Serbian Civil Code of 1844: A Battleground of Legal Traditions”, Thomas Simon, Gerd Bender und Jani Kirov (Hrsg.), Konflikt und Koexistenz Die Rechtsordnungen Südosteuropas im 19. und 20. Jahrhundert, Band II: Serbien, Bosnien-Herzegowina, Albanien, 2017, 431.

11 Иако је раније владало мишљење да је СГЗ заправо само скраћена верзија АГЗa, у новијој литератури се такво мишљење оспорава. О расправи о томе да ли је СГЗ само преписан АГЗ или не вид: С. Аврамовић, „Српски грађански законик (1844) и правни транспланти - копија аустријског узора или више од тога?", СГЗ - 170, 2014, 14. и даље; о нормама које су преузете из СС вид. S. Avramović, „The Serbian Civil Code”, 431-435.

12 То је институт који се примењује у случају када оставилац нема потомке, односно нема браћу ни сестре (брат и сестра су названи „привилегованим колатералима”, односно „collatéraux privilégiés”). Тада сваки родитељ као привилеговани асцендент наслеђује половину заоставштине, а свака половина постаје независна од друге, па чак и у случају да је један од његових родитеља умро, ту половину неће наследити преживели родитељ него асценденти умрлог родитеља. Нпр. оставилац нема преживелог супружника, потомке или привилеговане колатерале, а нема ни оца. Једино су му остали мајка и деда и баба по оцу. У овом случају, половину добија мајка, а другу половину (коју би добио отац да је жив), деле деда и баба по оцу, па они добијају по четвртину. Вид. детаљније и уз више примера у: Fente successorale: quest-ce que c'est?, https://www.capital.fr/ votre-argent/fente-successorale-1343470, приступљено 30. октобра 2020.

13 Kenneth Reid, Marius Johannes De Waal, Reinhard Zimmermann, Comparative Succession Law, Intestate Succession, Oxford University Press, Oxford 2015, 73. 
Рад се бави питањима положаја жене у браку (одредбе које регулишу склапање брака, развод брака, односно сепарацију, питања држављанства у ИГЗ-у и вере у СГЗ-у, односе супружника, односе родитеља и деце, пословну способност жене у браку) и њеног статуса у погледу наслеђивања (законског и тестаменталног).

\section{1. Поређење правног положаја жене у браку}

Сматрамо да су норме о положају жена у браку оне које највише сведоче о њиховом лошем правном статусу. Наиме, жена која није у браку ужива бољи положај од оне удате. Треба имати на уму, додуше, да положај неудате жене и удовице у СГЗ-у свеједно нису добри, јер удовица не може наследити свог мужа, односно родитељи задржавају право власти над женом до удаје. Једино би се положај жене након развода брака изједначио са положајем мушкарца. ${ }^{14}$ Са друге стране, у италијанском праву положај неудате жене, односно удовице је скоро једнак положају мушкарца, те она има у суштини иста права као она која има мушкарац, уз пар изузетака. ${ }^{15}$ Можемо зато рећи да је положај удате жене модификован браком као уговором који везује жену за мужа, који јој даје потчињен положај и зависности у односу на мужа. ${ }^{16}$ Зато, највећи део нашег рада ће бити управо посвећен нормама које се баве овим питањем, јер, посматрајући само одредбе о пунолетним женама ван брака, могао би се стећи утисак да оне нису обесправљене, што свакако јесте случај у посматраним законицима.

\subsection{1. Склайане брака, развоg/сейарација и држављьнсииво и вера}

У погледу склапања брака, још од старог века, ${ }^{17}$ постоји дуга традиција прописивања нижег узраста за ступање у брак за жене,

$14 \$ 38$. СГЗ-а. Вид. Марко Павловић, „Положај жене по српском грађанском зако-

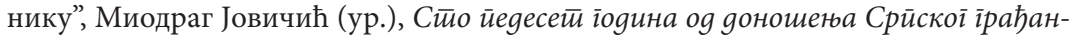
скої законика (1844-1994), Зборник раgова са научної скуйа оgржаної 23. и 24. маја 1994, 1996, 208-209.

15 Чл. 55, 268, 2097. ИГЗ-а. Вид. Angiolo Burri, Dei diritti delle donne secondo il Codice Civile del Regno d'Italia, Tip. Salani, Firenze 1869, 4.

16 A. Burri, 4.

17 То се може илустровати уз пример старог Рима. Наиме, минимална прописана старосна граница за склапање брака за жене је била 12 година, а за мушкарце 14. Штавише, неке девојке из аристократских породица су се удавале и раније. Мушкарци су се, у пракси, ретко женили пре 16. или 17. године. Вид. Carroll Moulton, Ancient Greece and Rome: An Encyclopedia for Students (4 Volume Set), Scribner, New York 1998, 274 (доступно на: Ancient History \& Civilisation, MARRIAGE AND DIVORCE, https://erenow.net/ancient/ancient-greece-and-romean-encyclopedia-for-students-4-volume-set/274.php, приступљено 13.10. 2020). 
због (у просеку) бржег сазревања. Тај принцип следе и ИГЗ и СГЗ. Наиме, уколико су родитељи дали своју сагласност, према ИГЗ-у мушкарац не може ступити у брак пре навршене осамнаесте године, а жена пре навршене петнаесте године, док у СГЗ-у постоји једино разлика по питању година мушкарца, где је прописан минимални узраст од седамнаест година за склапање брака, док је женин минимални узраст исти као онај предвиђен у тадашњој Италији. ${ }^{18}$ ИГЗ такође прописује да не постоји могућност ступања у брак без пристанка оца и мајке за сина који није навршио двадесет пет година и за ћерку која није навршила двадесет и једну годину, док је, према СГЗ-у, у том случају минималан узраст осамнаест година и за мушкарце и жене. ${ }^{19}$ Дакле, могу се приметити две разлике у односу на решење у СГЗ-у. Значајнија разлика се огледа у томе што је у ИГЗ-у прописан различит узраст за мушкарце и жене, док СГЗ прописује исти. Такође, узраст који предвиђа СГЗ је мањи у односу на онај прописан у ИГЗ-у. Полна дискриминација се огледа и у чињеници, да, уколико се родитељи не слажу, ИГЗ предвиђа да је довољан очев пристанак. ${ }^{20}$ Оно што је свакако битно напоменути јесте да се и мајка може супротставити браку своје деце. ${ }^{21}$ Са друге стране, СГЗ прописује да отац даје одобрење за синовљево ступање у брак, и да „до осамнаесте године дечије то његово одобрење не може бити замењено ничијим другим одобрењем" ${ }^{22}$ Изузетно релевантно је питање вере, ${ }^{23}$ те није

18 Чл. 55. ИГЗ-а, односно $\$$ 69, тач. 2 СГЗ-а. ИГЗ: „Не могу склопити брак мушкарац пре навршења осамнаесте године, а жена пре навршења петнаесте” („Non possono contrarre matrimonio l'uomo prima che abbia compiuto gli anni diciotto, la donna prima che abbia compiuto gli anni quindici”). СГЗ: „У брак законо ступити и венчани бити не могу: Ако младожења није навршио 17., а девојка 15. годину, осим случаја разрешења од надлежног Архијереја учињеног" (тач. 2). Чл. 1-365. ИГЗ доступни на: Codice Civile del Regno d'Italia - dall' art. 1 all' art. 365, https:// www.notaio-busani.it/download/docs/CC1865_100.pdf, приступљено 19. фебруара 2020 (превод свих чланова ИГЗ-а је наш). Целокупан текст СГЗ-а доступан на: Иван Д. Петковић (прир.), Грађански законик за Кратьевину Србију - Објаштен оgлукама Касаиионої суgа у Беоіраgу, Београд 1939, 1-356.

19 Чл. 63, ст. 1 ИГЗ-а, односно $\$ 69$, тач. 3 СГЗ-а.

20 Чл. 63, ст. 1 ИГЗ-а.

21 Вид. чл. 82. ИГЗ-а.

22 Милош М. Јовичић, Правни оgноси у йородици, Лични оgноси међу суйружнииима. Роgииеелькко йраво, Београд 1935, 19. Вид. 73. § СГЗ-а, који говори о ситауцији када свештеник без допуштења родитеља венча момка и девојку пре навршења њихове осамнаесте године, у којем случају брак ипак постоји, али свештеник одговара духовном суду.

23 Вид. \$91. СГЗ-а, који говори о обавези да се брак склопи у цркви, у време које је црква прописала и сходно правилима цркве. Са друге стране, у Италији дејства производи само грађански брак. Вид. Raffaella Pasquili, „La famiglia nel 
дозвољен брак између хришћана и нехришћана, који ће бити ништав ако се склопи. ${ }^{24}$

Док српски законодавац видно даје значај питању вере, италијански законодавац разматра на више начина како брак може да утиче на држављанство. Пре свега, дискриминација жене се огледа у томе што је држављанин онај чији је отац италијански држављанин, ${ }^{25}$ a тек уколико је он непознат, биће држављанин уколико је његова мајка држављанин. ${ }^{26}$ Странкиња која се уда за држављанина Италије стиче држављанство, а задржава га и ако постане удовица. ${ }^{27}$ Жена која има италијанско држављанство а која се уда за странца постаје странкиња, под условом да чињеницом брака стекне држављанство супруга, ${ }^{28}$ а жена и малолетна деца странца који је добио држављанство постају држављани Италије ако је њихово пребивалиште у Краљевству, али деца могу да одаберу да остану странци. ${ }^{29}$ Питање утицаја брака на држављанство у српском праву је регулисано тако што Српкиња ${ }^{30}$ губи српско држављанство у случају удаје за странца, а странкиња добија српско држављанство у случају удаје за Сpбина, под условом реципроцитета. ${ }^{31}$ Иако се не помиње изричито у СГЗ-у, сматрамо да је битно напоменути да, по тадашњем српском праву, када странац стекне српско држављанство прирођењем, то

tempo", Silvana Serafin, Marina Brollo (ed.), Donne, politica e istituzioni: il tempo delle donne, Forum, Udine 2013, 224-225.

$24 \$ 79$. СГЗ-а. Касније ће Брачна правила Српске православне цркве из 1933. прописати да ће брак остати на снази уколико нехришћанин пређе у православну веру, па тиме престане разлика у вери ( $\$ 49$, тач. 2$)$. Правила доступан на: И. Петковић, 437-470.

25 Чл. 4. ИГЗ-а. При том је ирелевантно да ли ће дете бити рођено у Краљевини или у иностранству. Felice Voltolina, Commento al codice civile del regno d'Italia 25 giugno 1865 colle relative leggi romane, colle opinioni e dottrine de' piu celebri scrittori di diritto e di legislazione, colle indicazioni delle leggi napoleoniche ed austriache nonche delle patrie sparse in altri codici Felice Voltolina, Tipografia Municipale di Gaetano Longo, Venezia 1873, 43-44.

26 Чл. 7. ИГЗ-а.

27 Чл. 9. ИГЗ-а.

28 Ако постане удовица, може да врати држављанство ако живи у Краљевству или ако се врати и ако изјави пред службеним лицем да жели да ту заснује пребивалиште. Чл. 14. ИГЗ-а.

29 Чл. 10. ИГЗ-а.

30 Ради објашњења термина „Србин” и „Српкиња” треба посматрати чл. 2. СГЗ-а, према коме су одређена „права и дужности Србина према брату Србину”. Мирковић упорећује овај члан са чл. 1, у коме је установљен територијални принцип. Вид. Зоран С. Мирковић, „Уводна правила и увођење у живот Српског грађанског законика", СГЗ - 170, 2014, 77 и даље.

$31 \S 48$. СГЗ-а. 
аутоматски важи и за његову жену и малолетну децу. ${ }^{32}$ Реч је о норми која је у интересу породице као целине, али која, с друге стране, дискриминише жену.

Што се тиче престанка брака, треба напоменути да ИГЗ изричито говори да брак може престати само смрћу, ${ }^{33}$ што значи да није могуће развести га. ${ }^{34}$ Ипак, постоји могућност „личне сепарације”. 35 Решење у СГЗ-у је боље јер се као разлози развода наводе само рађење о глави супружнику, осуда на дуготрајну робију, одступање из хришћанске вере, „неизвесна или злоковарна” одсутност ${ }^{36}$ и доказана прељуба, ${ }^{37}$ при чему није изричито прецизирано да ли се ради о прељуби коју је учинила жена или муж. Иако у италијанском праву брак може престати само смрћу, а не и разводом, ${ }^{38}$ могуће је тражити сепарацију из више разлога (али само у случајевима који су предвиђени у закону): ${ }^{39}$ због намерног напуштања и због мучења, претњи

32 Лазар Марковић (прир.), Грађански законик Краљевине Србије са крайким објашюенима, Друго издање, Издавачка књижара Геце Кона, Београд 1921, 22.

33 Чл. 148. ИГЗ-а.

34 На први поглед, могло би се помислити да су на овакво законодавно решење утицали највише религијски разлози, међутим, то није случај. Наравно, законодавац није хтео да погорша већ лоше односе са католичким светом, али то није био пресудан мотив за усвајање оваквог решења. Наиме, да би се разумело искључење могућности за развод, треба посматрати период пре доношења ИГЗ-а. Током периода Наполеонове владавине, када је у Италији било могуће развести брак, мали број супружника је прибегавао том решењу, па није било ни потребно задржати такво решење. Поред тога, чл. 148. ИГЗ-а представља вид заштите за жену. 39-40. Loredana Garlati, „La famiglia tra passato e presente”, Salvatore Patti, Maria Giovanna Cubeddu (ed.), Diritto della famiglia, 2011, 41-42.

35 Сепарација заправо јесте институт који се у старијем српском праву означавао термином „растава (од стола и постеље)”. Међутим, с обзиром на то да се у ИГЗ-у користи термин „separazione (personale)”, користићемо у даљем тексту управо термин „(лична) сепарација”.

36 Тек по истеку рока од 6 година од времена одсуства супружника је могуће „дати молбу духовноме суду поради разведења брака свог”. Уколико се одсутни супружник за једну годину не нађе, нити се јави другом супружнику, брак се може развести. Вид. \$95. СГЗ-а.

37 3. Мирковић, Срйска йравна исӣорија, Правни факултет Универзитета у Београду, Београд 2017, 149. Вид. \$ 94. СГЗ-а. Прељуба која може довести до развода није „свака блудна радња, него само блуд, обљуба”, јер она која се састоји у „некој другој блудној радњи не повлачи за собом развод брака, него само одвојен живот који се, после пет година, може претворити у развод брака". Тужба за прељубу треба да буде поднета одмах, јер се у супротном прељуба сматра опроштеном. Вид. Живојин Перић, Лично брачно ирраво йо Срйском ірађанском законику, Библиотека за правне и друштвене науке, Београд 1934, 51-52; Л. Марковић, Грађански законик, 46-47.

38 R. Pasquili, 225.

39 Чл. 149. ИГЗ-а. 
и тешких увреда или прељубе, а управо у погледу прељубе се може видети бољи положај мужа: поступак сепарације због мужевљеве прељубе није дозвољен, осим у случају када он издржава конкубину у кући или на другом месту или су околности такве да чињеница представља озбиљну увреду његове жене. ${ }^{40}$

После престанка брака, могуће је поново склопити брак, али уз извесна ограничења. ИГЗ предвиђа да жена не може склопити нови брак пре протека рока од десет месеци од престанка ${ }^{41}$ или поништења претходног брака, а ова забрана престаје уколико се жена породи. ${ }^{42}$ Са друге стране, према СГЗ-у, може се поново венчати само она страна која није крива за развод брака. ${ }^{43}$ Ипак, разведена жена која није скривила развод брака, не може пре порођаја да се преуда ако је трудна. ${ }^{44}$ Уколико је трудноћа неизвесна, не може се преудати пре протека рока од девет месеци после развода (дакле, предвиђено је време које је краће месец дана у односу на решење усвојено у ИГЗ-у), осим ако се на суду од стране вештака докаже да није трудна, у ком случају се може удати протеком рока од шест месеци. ${ }^{45}$

\subsection{2. Оgноси суйружника}

Положај жене у браку у СГЗ-у и ИГЗ-у46 би се могао објаснити чињеницом да је жена зависна од мужа. И један и други законодавац предвиђају мужа као главу ${ }^{47}$ породице: ${ }^{48}$ супруга прати његов цивилни

40 Чл. 150. ИГЗ-а. Женина прељуба се у италијанском праву задржала као кривично дело чак до 1969. године. E. Cantarella, Prefazione.

41 Мисли се на престанак брака услед смрти супружника.

42 Чл. 57. ИГЗ-а. Једини изузетак од овог правила је предвиђен у члану 107, који говори о трајној немоћи, која је настала пре склапања брака, због које други супружник може тражити поништење брака.

$43 \S 101$. СГЗ-а.

44 В. Станимировић, 157.

$45 \$ 105$. СГЗ-а.

46 Тако, Стефанија Лићини (Stefania Licini) наводи да је у тек формираном Италијанском краљевству потврђена подређеност жене у односу на мушкарца увођењем новог грађанског законика. Вид. Stefania Licini, „Women, wealth and finance (19th century Italy)", Working papers at the Hyman P. Minsky Dep. of Economic Studies - Quaderni del Dip. di Scienze economiche Hyman P. Minsky, 2006 (доступно на: Women, wealth and finance. (19th century Italy), https://www.researchgate.net/ publication/4923924_Women_wealth_and_finance19th_century_Italy, приступљено 13. септембра 2020).

47 Милош Јовичић сматра да би било погрешно схватити овај израз у апсолутном смислу, јер се он односи само на правне односе. Вид. М. Јовичић, 9.

48 На питање због чега је неопходно у закону одредити некога као централну фигуру у породици, Перић објашњава да је нужно одредити некога као шефа било 
статус, преузима његово презиме и дужна је да га прати где год он да одреди пребивалиште. ${ }^{49}$ у погледу пребивалишта, италијански законодавац даље прописује да жена нема друго пребивалиште од мужевљевог, ${ }^{50}$ да ће се законским пребивалиштем увек сматрати пребивалиште мужа, па чак и онда када она станује на неком другом месту, ${ }^{51}$ да супруга која није законски одвојена од мужа има пребивалиште мужа и да ће га задржати док не стекне друго, када постане удовица. ${ }^{52}$ Српско право даје могућност жени да „одбије да иде са мужем тамо где би то за њу било немогућно или штетно са гледишта њенога доброга гласа, сигурности, живота или здравља". ${ }^{3}$ Даље, ИГЗ говори да муж има обавезу да штити своју жену, да је држи близу и да јој даје све што је неопходно за животне потребе сразмерно његовим могућностима; жена мора да допринесе издржавању мужа ако он нема довољно средстава. Даље, једино је муж овлашћен да располаже имовином током брака, а само он одговара повериоцима, може да прибира плодове и камате и да захтева повраћај новца. ${ }^{54}$ Муж може самостално да управља стварима из заједничке имовине, али не може да располаже самостално. ${ }^{55}$

Међусобни односи мужа и жене и дужности у брачној заједници у СГЗ-у регулисани су на следећи начин: „оба супружника дужна су љубавно међу собом и неразделно живети, дужности брачне изврша-

које заједнице, јер би се заједница распала да није одређен центар „око кога се заједница окреће и према коме гравитира”. Наиме, „када заједница брачнопородична не би имала свога центра, свога шефа, она се не би одржала, она би се распала услед тежње свакога члана заједнице за самосталним, индивидуалним животом". А положај шефа породице није дат жени јер су законик писали мушкарци. Вид. Ж. Перић, Лично брачно ӣраво, 63.

49 Чл. 131. ИГЗ-а, коме одговара \$ 110. СГЗ-а. „Супруга пак дужна је мужа свога слушати, наредбе његове набљудавати, за њим ићи и где он за добро нађе, с њиме онде живети; њему по силама својим у отправљању домаћих послова, у прибављању, а нарочито чувању имања припомагати, и кућевни ред и чистоту набљудавати, и нарочито децу намиривати, у чистоти и благонаравију садржавати и чувати". Иако део о помагању у прибављању и очувању имовине није одређен законом, говори се о томе да је жена „по потреби дужна да према својим способностима помаже мужу и својим личним радом у тековини и да приходе од тог рада уноси за подмирење брачних потреба". М. Јовичић, 8.

50 Чл. 18. ИГЗ-а.

51 A. Burri, 21.

52 Чл. 18. ст. 1 ИГЗ-а.

53 Ж. Перић, Лично брачно йраво, 65-66.

54 Чл. 1399. ИГЗ-а. Чл. 1224-1661. ИГЗ-а доступни на: Codice Civile del Regno d'Italia - dall' art. 1224 all' art.1661, https://www.notaio-busani.it/download/docs/ CC1865_400.pdf, приступљено 08. марта 2020.

Чл. 1438. ИГЗ-а. 
вати, једно другом верни ${ }^{56}$ бити, пристојно једно друго предусретати, и у сваком случају у помоћи бити",57 што предвиђа и италијански законодавац тако што наводи да брак супружницима намеће обострану обавезу заједничког живота, верности и помоћи. ${ }^{58}$ Израз „помоћ” се међутим не односи на финансијску помоћ, јер, како каже Станимировић, „жени (је) остављен рад у кући и брига о деци, док је муж тај који издржава своју супругу и читаву породицу", јер би за мушкарца било срамотно да га издржавају жена или њена породица. ${ }^{59}$ „Муж је дужан да своју жену издржава, да је храни и одева у складу са својим могућностима, али и брани и заступа". 60 У случају задужења жене код других лица због кућних трошкова, муж мора према закону да исплати те дугове. Такође, дужан је да надокнади жени „све трошкове које је она учинила из својих сопствених средстава за своје и кућевне потребе".61

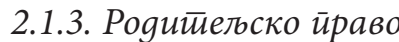

У ИГЗ-у је прописано да дете, без обзира на године, мора да поштује родитеље, а слично решење предвиђа и СГЗ у $\$ 120 .{ }^{62}$ ИГЗ даље говори да је дете подложно родитељској власти до пунолетства или еманципације, али родитељи у том погледу нису изједначени. Наиме, за време брака ову власт, која је у закону названа podestà врши отац, а ако он то не може, онда мајка. ${ }^{63}$ Како то каже Ана Марија Моцони (Anna Maria Mozzoni), при разматрању института patria potestas „почињу да се осећају утицаји античког света”. ${ }^{4}$ Иако је у начелу

56 Верност обухвата полну, односно телесну и духовну, односно психичку верност. Вид. Ж. Перић, Лично брачно йраво, 51.

$57 \$ 108$. СГЗ-а. Ови односи су моралне природе, иако су „моралне обавезе подигнуте на степен правних", али, у случају њиховог неиспуњења, није предвиђена директна принуда као санкција, јер се „непосредна принуда не слаже са самом природом брачне заједнице”. М. Јовичић, 4-5.

58 Чл. 130. ИГЗ-а.

59 В. Станимировић, 152-153.

60 3. Мирковић, Срйска йравна истиорија, 148.

61 М. Јовичић, 6.

62 Чл. 220, ст. 1 ИГЗ-а: „Дете, без обзира на узраст, мора да одаје част и поштовање родитељима” („Il figlio, qualunque sia la sua etá, deve onorare e rispettare i genitori”). СГЗ: „Деца су дужна родитеље своје поштовати, и у свачему њима послушни бити, и противу воље њихове ништа не чинити, нити предузимати (...)”. То је учињено стога што се на родитељски ауторитет гледало као на свету, на најприроднију ствар, а остале дужности деце према својим родитељима произилазе управо из дужности поштовања родитеља. Вид. F. Voltolina, 280-281.

63 Чл. 220, ст. 2-4 ИГЗ-а.

64 "Cominciano a sentirsi le ispirazioni del mondo antico”. Anna Maria Mozzoni, La donna in faccia al progetto del nuovo codice civile italiano, Tipografia sociale, Milano 1865, 7. 
предвиђено да ће жена вршити patria potestas само ако је удовица, ${ }^{65}$ a муж није тестаментом предвидео старање о имовини и деци, судови у Краљевини су проширили ову могућност на све случајеве у којима муж не може да врши ову власт, зато што је нпр. одсутан. ${ }^{66}$

Српски грађански законик оба родитеља начелно сматра дужним да се старају о детету, са тим што дужности нарочито леже на оцу, ${ }^{67}$ (што је у основи исто решење као и оно италијанско), у чему се огледа потчињеност супруге мужевљевој власти током трајања брака. Наиме, „иако се појављује у многим односима према брачној деци уз оца и поред оца - никада нема самосталан положај родитеља који врши родитељско право". 68 Са друге стране, о ванбрачној деци је дужна да се стара мајка, осим у случају њиховог позакоњења. ${ }^{69}$ Уопште, дужности родитеља да издржавају ${ }^{70}$ своју децу постоје све до стицања пунолетства или навршења двадесет прве године код мушкараца, односно до удаје код жена (законодавац подразумева да ће се девојке пре тог доба удати). ${ }^{71}$ Потврда за то јесте ситуација коју предвиђа $\$ 153$. СГЗ-а који говори о ступању у однос супружничких права и обавеза малолетне девојке која се удала. Наиме, „синовима је родитељска власт престајала са пунолетством, док су девојке удајом само мењале господара, уместо родитеља власт над њима преузимали су њихови мужеви, односно њихови родитељи ако су били малолетни у моменту склапања брака". ${ }^{2}$ У случају престанка очинске власти, „деца не долазе аутоматски под власт мајке, него им се она једино може поставити за старатеља", а мушка деца која су навршила

65 Ово правило уводи ИГЗ. Вид. Marzio Barbagli, David I. Kertzer, Storia della famiglia italiana, 1750-1950, Il Mulino, Bologna 1992, 147.

66 Eligio Imarisio, Donna poi artista: identità e presenza tra Otto e Novecento, FrancoAngeli, Milano 1996, 33-34.

$67 \$ 115$. СГЗ-а.

68 Марија Драшкић, „Усвојење и хранитељство - добра традиција српског грађанског законика?", СГЗ - 170, 2014, 128.

$69 \$ 135$. СГЗ-а. Позакоњена деца су ванбрачна деца која су накнадно стекла статус брачне деце. Овај институт је познат и данас у неким законодавстима (па и у италијанском), али је напуштен јер су данас брачна и ванбрачна деца правно изједначена. Институт позакоњења не познаје српско позитивно право. Germano Palmieri, Dizionario dei termini giuridici, Nuova edizione ampliata e aggiornata, Biblioteca Universale Rizzoli, Milano 2006, 392, 393; М. Драшкић,

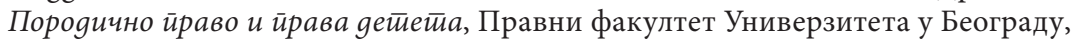
Београд 2015, 190.

70 У издржавање деце „спада прибављање средстава и подношење трошкова за исхрану деце, њихов стан и одело”. М. Јовичић, 16. Вид. \$ 115. СГЗ-а.

71 В. Станимировић, 158. Вид. \$117. СГЗ-а.

72 В. Станимировић, 158. 
четврту годину, односно женска деца која су навршила седму, поверавају се оцу, а не мајци у случајевима развода или одвојених живота супружника. ${ }^{73}$ Он је такође заступник своје малолетне деце. ${ }^{74}$

Занимљиво је навести једно решење присутно у оба законика у погледу решавања ситуације у вези са истраживањем очинста: наиме, оба законика изричито прописују да није дозвољено истраживање очинства, осим у случајевима отмице ${ }^{75}$ и силовања, када време отмице или силовања одговара времену зачећа. ${ }^{76}$ ИГЗ предвиђа да је дозвољено истраживање материнства, ${ }^{77}$ што је још једна одредба у којој постоји полна дискриминација.

\subsection{4. Пословна сйособности жене у браку}

Пословна способност жене је у браку веома ограничена. ИГЗ предвиђа да супруга не може поклањати непокретну имовину, располагати њоме и стављати под хипотеку и да јој се не може судити због предузимања таквих аката без одобрења њеног супруга. Од тренутка склапања брака, жена остаје власник ствари које је стекла пре

73 М. Драшкић, „Усвојење и хранитељство”, 128-129.

$74 \$ 126$. СГЗ-а.

75 Отмица девојака је била „један од начина да се стигне до невесте, али су се неретко и девојке одлучивале да пркосе намери родитеља и њиховом избору, бекством од куће и добегавањем вољеном младићу”. Вид. \$ 89. СГЗ-а, који посредно доказује учесталост овог обичаја. Иначе, ванбрачна трудноћа је међу Србима сматрана срамотом чак и онда када би настала из отмице. Супротно мишљење (када је реч о Шумадији) вид. у: Сретен Л. Поповић, Пуйоване йо новој Србији 1878. и 1880, Београд 1950; Миленко С. Филиповић, Таково, Београд 1960. Настојало се да се „избегне свака сумња у одржавање ванбрачне сексуалне везе између будућих супружника. Брак би био одмах склопљен по православном обреду, или би невеста по отмици до венчања живела ван куће будућег супруга”. В. Станимировић, 153-154; Андреја Катанчевић, „Трошкови порођаја и српски грађански законик", СГЗ - 170, 2014, 345.

76 Чл. 189. ИГЗ-а, коме одговара $\$ 130$. СГЗ-а (то није изворни текст чл. 130. СГЗ-а, него његова измена из 1868). ИГЗ: „Истраге о очинству нису дозвољене, осим у случајевима отмице или насилног силовања, када њихово време одговара времену зачећа” („Le indagini sulla paternità non sono ammesse, fuorchè nei casi di ratto o di stupro violento, quando il tempo di essi risponda a quello del concepimento"). СГЗ: „Ко је отац ванбрачном детету не сме се истраживати и доказивати, осим ако је случај одвођења ( $\$$ 188. и 189. Казненог законика), или силовања ( $\$ 191$. истог Законика), па би се време затрудњења подударало са временом одвођења или силовања, а и само на тужбу оних, којих се тиче. Тако исто не сме се ванбрачно дете на име кога другога, осим на име материно у црквене књиге увести, ван ако ко сам призна да је отац детету, и одобри да се оно на његово име у црквене књиге уведе".

77 Чл. 190. ст. 1 ИГЗ-а. 
брака, али не може њима да управља. ${ }^{78}$ Муж може дати, изричито или прећутно, ${ }^{79}$ јавно овлашћење (autorizzazione maritale) $)^{80}$ жени да предузима неке или све наведене послове, а може своје овлашћење и повући, ${ }^{81}$ а неће се тражити његова сагласност када је жена законски „одвојена” од њега због његове кривице и у другим случајевима предвиђеним законом. ${ }^{82}$ Даље, у законику је предвиђено да жене, осим оних које су преци или неудате пунородне сестре, не могу бити старатељи. ${ }^{83}$ Акта и изјаве које треба дати у присуству државних службеника могу дати само мушкарци који су навршили двадесет једну годину и који имају пребивалиште у тој општини, ${ }^{84}$ а не могу их давати жене.

У СГЗ-у је пословна способност жене ограничена, па се може рећи да постоји донекле слично решење, али ипак под другачијим околностима прописано. Наиме, српски законодавац прописује да жена губи пословну способност моментом склапања брака, када се она изједначава са лицима која су „ума лишена, распикуће судом проглашене и презадуженици којих је имање под стециште потпало". ${ }^{5}$ Интересантно је навести да пословна (не)способност жене није прописана у јединственом члану, иако су разлози пословне неспособности умоболника (ментално оболелих), расипника (лица под стечајем) и пропалица у потпуности другачији од разлога због којих је удата жена пословно неспособна. ${ }^{86}$ Овакво одређење у најбољој мери описује њен потчињен положај који са собом носи и бројне појединости као што је чињеница

78 Супружницима је ипак остављена могућност склапања брачних уговора којима би се одступало од система посебних имовина супружника који је прописан законом. S. Licini, „Donne e ricchezza: suggerimenti da una fonte fiscale (Milano, 1862-1900)", Working papers at the Hyman P. Minsky Dep. of Economic Studies Quaderni del Dip. di Scienze economiche Hyman P. Minsky, 2004, 6 (доступно на: Donne e ricchezza: suggerimenti da una fonte fiscale (Milano, 1862-1900), https://

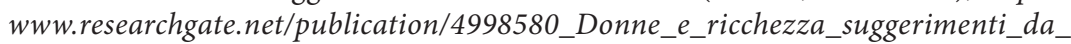
una_fonte_fiscale_Milano_1862-1900, приступљено 10. септембра 2020);.

79 F. Voltolina, 184.

80 Autorizzazione maritale је иначе институт који није био предвиђен у изворном тексту законика који је написао Пизанели (Pisanelli) 1863, већ га је накнадно додао нови министар Вака ( $\mathrm{Vacca}$ ) који га је сматрао „залогом породичног мира и хармоније између супружника". Укинут је тек 1919. Вид. L. Garlati, 41-42; G. Galeotti, 163. и даље; R. Pasquili, 225.

81 Чл. 134. ИГЗ-а.

82 Чл. 135. ИГЗ-а.

83 Чл. 268, ст. 1 ИГЗ-а.

84 Чл. 351. ИГЗ-а.

$85 \$ 920$. СГЗ-а.

86 М. Драшкић, „Усвојење и хранитељство”, 129. 
да „без мужевљеве сагласности не може да склапа правне послове,${ }^{87}$ да буде одређена за старатеља ${ }^{88}$ нити је била равноправни члан породичне задруге", 89 што нас наводи на закључак да је, у овом погледу, њен положај прилично изједначен у оба законика. Како каже Станимировић, законодавац је „од удатих жена начинио пуке послушнике ${ }^{90}$ осакативши им пословну способност". ${ }^{91}$ Штавише, њен положај је гори од положаја малолетника између седме и петнаесте године, јер њима није потребно одобрење оца или старатеља да би примили поклоне, док је жени потребна сагласност мужа чак и у том случају, а они могу бити и пуномоћници без ичијег одобрења, док је жени потребно одобрење мужа. ${ }^{92}$

\section{2. Поређење правног положаја жене у погледу наслеђивања}

\subsection{1. Законско наслеђиваюе}

Законско наслеђивање јесте област у којој су лако уочљиве разлике и у једном и у другом законику у односу на њихове узоре. Крупне разлике се поготово могу приметити између СГЗ-а и АГЗ-а, због чега Сима Аврамовић доводи у питање владајуће мишљење да је СГЗ копија АГЗ-а. ${ }^{93}$ И законско наслеђивање у ИГЗ-у се разликује од свог узора јер је предвиђено за сроднике до десетог степена, а не дванаестог као у Француском грађанском законику. ${ }^{94}$

Иако је СГЗ преузео парентеларни систем из АГЗ-а, правила нису преузета у целини, што је довело до стварања једног прилично компликованог система законског наслеђивања. ${ }^{95}$ Оно је уређено по прин-

87 Као и у италијанском праву, муж даје одобрење за послове које предузима жена. У случају да нема пристанка мужа, посао није пуноважан и не обавезује жену, која се може позивати на неважност тог посла. Наравно, одобрење се може дати и накнадно. М. Јовичић, 11.

88 Штавише, може бити старатељ само у случају да је мајка. Вид. В. Станимировић, 157.

89 3. Мирковић, Срӣска йравна истиорија, 149-150.

90 Женина дужност слушања, међутим, није апсолутна и има одређене границе, које се тичу „духовне индивидуалности и независности женине”. Примера ради, жена има право да има другу веру од мужевљеве, али само након закључења брака, јер се иначе брак не може ни склопити. Вид. Ж. Перић, Лично брачно ирраво, 69. и даље.

91 В. Станимировић, 156.

92 М. Јовичић, 11; Ж. Перић, Лично брачно ирраво, 82.

93 С. Аврамовић, „Српски грађански законик”, 16. и даље.

94 K. Reid, M. J. De Waal, R. Zimmermann, 73.

95 Л. Марковић, Наслеgно ирраво, Београд 1930, 77. Неке од разлика у односу на АГЗ види у: С. Аврамовић, „Српски грађански законик”, 13-46. 
ципу да само мушки потомци оставиоца у оквиру првог наследног реда могу бити његови наследници, који добијају подједнаке делове, док „женској деци припада у овом случају само уживање, издржавање, снабдевање и пристојно удомљење по постојећем обичају".96 У случају да оставилац има само женску децу, онда она наслеђују заоставштину такође на једнаке делове, уз могућност примене права представљања. ${ }^{97}$ „Овакав однос према женама као могућим законским наследницама законодавац је пресликао и на остале наследне редове”.98

Грађански законик краљевине Италије ${ }^{99}$ у погледу законског наслеђивања ${ }^{100}$ предвиђа супротно решење: предвиђена једнакост наследника, независно од њиховог пола, али само у погледу „леги-

96 \$397. СГЗ-а. Треба напоменути да је Хаџић сматрао да женска деца треба да добију право на законско наслеђивање, а та решења је и унео у нацрт који је предао 1842. кнезу Александру Карађорђевићу. Додуше, разлог за овакво схватање се налази у томе што тадашњи савремени законици нису ускраћивали женама право да наследе, а не у томе што је он хтео да се њихов положај побољша. Овакво решење критикује и Димитрије Матић, који сматра да ниједан грађански законик не ускраћује ћерки право да наследи јер ограничавањем права наследства ћерки полови постају неравноправни, а тиме се нарушава природна правда. Вид. Урош Станковић, „Хиљаду осамсто четрдесет шеста - наследноправни положај женске деце по трећи пут на дневном реду”, СГЗ - 170, 2014, 409; Димитрије Матић (прир.) Објаснење Грађанскоі законика за Кюажесииво срйско 2/1, Београд 1851, 540-544; В. Станимировић, 147.

$97 \$ 400$. СГЗ-а. Димитрије Матић је становишта да је боље решење да женска деца само наследе мањи део од дела мушкараца, односно да син може својој сестри да исплати новчану противвредност њеног дела заоставштине и тако да стекне својину на целој заоставштини. Вид. Д. Матић, 543.

98 М. Драшкић, „Усвојење и хранитељство”, 129.

99 Интересантно је навести да су се одредбе о сукцесији налазиле у поглављу „О начинима стицања и преноса имовинских и других права на ствари” („Dei modi di acquistare e di trasmettere la proprietà e gli altri diritti sulle cose"), што је било лоше решење јер сукцесија не значи увек пренос, па је то промењено приликом доношења Грађанског законика 1942. године, у коме је поглавље о сукцесији лоцирано одмах иза оног о „људима и породици” („Delle persone e della famiglia”, са којим сукцесија има већу везу него што има са облигацијама. Са друге стране, одредбе о тестаменталном наслеђивању се у СГЗ-у налазе у више глава, а у оквиру одредби о наслеђивању се налазе и норме којима се уређују односи у задрузи. С. Аврамовић, „Српски грађански законик”, 25; W. D’Avanzo, „Successione”, Enciclopedia Italiana - II Appendice, XXXII, Treccani, 1949, 923 (доступно на: Successione, $h t t p: / / w w w . t r e c c a n i . i t / e n c i c l o p e d i a / s u c c e s s i o n e \_r e s-f 38 e 76 c d-$ 87e6-11dc-8e9d-0016357eee51_\%28Enciclopedia-Italiana\%29/, приступљено 26. априла 2020).

100 Изричито је прописано да се правила о законском наслеђивању примењују уколико недостаје тестамент или уколико се тестаментом располаже само делом заоставштине (чл. 720. ст. 2 ИГЗ-а). Чл. 366-765. ИГЗ-а доступни на: Codice Civile del Regno d'Italia - dall' art. 366 all' art. 765, https://www.notaio-busani.it/ download/docs/CC1865_200.pdf, приступљено 17. априла 2020. 
тимне квоте", 101 која износи једну половину заоставштине. То значи да је ипак могуће привилеговати неког наследника располагањем остатком заоставштине тестаментом. ${ }^{102}$ Наиме, предвиђено је да могу да наследе сви, осим оних којима је законом изричито забрањено да наслеђују, ${ }^{103}$ (нпр. особе које су намерно убиле или покушале да убију оставиоца, они који су принудили тестатора да сачини или промени тестамент итд), ${ }^{104}$ међу којима нису наведене жене. Овде се не јавља дискриминација на основу пола, већ се разликовање наследника врши независно од пола између брачне ${ }^{105}$ и ванбрачне деце, ${ }^{106}$ што се може видети из члана 806. у коме се говори да се одредбе о наслеђивању у којима се спомињу деца односе само на брачну децу, „позакоњену децу”, ${ }^{107}$ усвојену децу и њихове потомке. ${ }^{108}$

\subsection{2. Тесииаменйално наслеђиване}

У погледу тестаменталног наслеђивања, за разлику од законског, постоје велике сличности. Наиме, и према ИГЗ-у и према СГЗ-у жене могу, као и мушкарци, сачинити тестамент, ${ }^{109}$ али, такође, не могу

101 „Легитимна квота” („porzione legittima”) је назив који италијански законодавац користи за онај део заоставштине којим не може да се располаже у тестаменту, који мора да припадне деци (чл. 805. ИГЗ-а; чл. 767-1223. ИГЗ-а доступни на: Codice Civile del Regno d'Italia - dall' art. 767 all' art. 1223, https://www.notaiobusani.it/download/docs/CC1865_300.pdf, приступљено 18. априла 2020). Тај термин одговара српском термину „нужни наследни део” (Закон о наслеђивању - Сл. іласник РС, бр. 46/95, 101/2003 - одлука УСРС и 6/2015, чл. 40, ст. 1: „Нужним наследницима припада део заоставштине којим оставилац није могао располагати и који се назива нужним делом").

102 Laura Marchesano, „Alla ricerca di una moglie. Celibato rurale e migrazioni matrimoniali", Storicamente 6 nr. articolo 5, 2010 (доступно на: Laura Marchesano, Alla ricerca di una moglie. Celibato rurale e migrazioni matrimoniali, https://storicamente.org/marchesano_immigrazione_matrimoniale, приступљено 11. октобра 2020); S. Licini, „Women, wealth and finance”, 5 .

103 Чл. 723. ИГЗ-а. Вид. F. Voltolina, 882-885.

104 Вид. чл. 724-725. ИГЗ-а.

105 Брачна деца су у законику названа „природном децом” („figli naturali”).

106 Вид. ИГЗ, чл. 743-752, који посебно регулишу положај ванбрачне деце у законском наслеђивању.

107 „Legittimati”. Вид. G. Palmieri, 392, 393.

108 Чл. 806. ИГЗ-а.

109 Чл. 762-763. ИГЗ-а, односно $\$ \$ 426-428$. СГЗ-а. Чл. 762. ИГЗ-а: „Сви који законом нису проглашени неспособним могу располагати тестаментом” („Possono disporre per testamento tutti coloro che non sono dichiarati incapaci dalla legge"). Чл. 763. ИГЗ-а: „Нису у могућности да тестирају: 1. Они који нису навршили осамнаест година; 2. Они који су лишени пословне способности због болести ума; 3 . Они који нису били ментално здрави у тренутку састављања тестамента, иако нису лишени пословне способности (...)” („Sono incapaci di testare: $1 .^{\circ}$ Coloro che 
ни у једном ни у другом бити сведоци при састављању тестамента. СГЗ наводи изузетак када је то ипак могуће у случају крајње нужде, за које наводи пример опасности потопљења и бродолома, али и места где влада куга или нека друга зараза. ${ }^{110}$ ИГЗ предвиђа и да жене могу и наследити на основу тестамента, ${ }^{111}$ по истом принципу по којем га могу сачинити и наследити на основу законског наслеђивања. То, међутим, није изричито прописано, већ је реч о томе да могу наследити сви осим оних који су законом проглашени неспособним за наслеђивање, међу којима нису наведене жене. ${ }^{112}$ Као и код законског наслеђивања, дискриминација постоји у односу на ванбрачну децу. ${ }^{113}$

\section{3. ПОЛОЖАЈ ЖЕНЕ У ПОРОДИЧНОЈ ЗАДРУЗИ У СРПСКОМ ПРАВУ У ОПШТИМ ЦРТАМА}

Српски грађански законик предвиђа институт породичне задруге који није садржан у италијанској кодификацији. ${ }^{114}$ Овај инсти-

non hanno compiuto l'età di diciotto anni; $2 .^{\circ}$ Gli interdetti per infermità di mente; $3 .^{\circ}$ Quelli che, quantunque non interdetti si provin on essere sani di mente nel tempo in cui fecero testamento (...)”). $\$ 426$. СГЗ-а: „Ко нема свога сопственога имања, или нема власти с њим располагати, не може ни тестамента снажна начинити, и ако начини, не вреди ништа”. $\$ 427$. СГЗ-а: „Којигод разума и воље нема, тај ни последње воље имати не може. Дакле, који нису при свести; као: згранути, бесомучни, луди, распикуће судски за такве проглашене, младолетни млађи од 15 година, не могу правити завештања, и ако начине нема силе ни важности". \$ 428. СГЗ-а: „Сва остала лица, била мушка била женска, могу правити тестаменат, и биће снажан, ако је иначе у свом реду, и по пропису начињен, да закону достоверност има". Интересантно је навести да српски законодавац изричито наводи у $\$ 428$. да женска лица могу наслеђивати на основу тестамента, док италијански законодавац користи уопштено реч „сви”.

110 Чл. 788. ИГЗ-а, коме одговара $\$ 446$. СГЗ-а. ИГЗ: „Сведоци у тестаментима морају бити мушкарци, старији од двадесет и једне године, држављани краљевине или странци који у њему бораве и који нису осудом изгубили уживање или вршење грађанских права” („I testimoni nei testamenti devono essere maschi, maggiori di anni ventuno, cittadini del regno, o stranieri in esso residenti, e non aver perduto per condanna il godimento o l'esercizio dei diritti civili...”) СГЗ: „Ни жене, ни момци млађи од 17 година, као ни монаси да се не узимају за сведоке, осим особите нужде, нпр. на бродовима, где је опасност потопљења, или на месту где куга мори или друга зараза влада". Иако ова два члана имају исти смисао, може се још једном приметити разлика у формулацији: док италијански законодавац говори о томе да само мушкарци могу бити сведоци тестамента, српски изричито искључује жене и мушкарце који нису навршили седамнаесту годину.

111 Чл. 764. ИГЗ-а.

112 Вид. чл. 764-773. ИГЗ-а.

113 Вид. чл. 767. ИГЗ-а.

$114 \mathrm{C}$ једне стране, сама ова чињеница представља битну разлику између законика. C друге, због тога што није могуће поредити норме оба законика услед непо- 
тут, познат српском обичајном праву, увео је СГЗ, ${ }^{115}$ јер, како каже Никола Павковић, „све до појаве Србијанског грађанског законика, у српским земљама које су биле под турском влашћу није било писаних закона о породичној задрузи". 116 Да би задруга (кућа или кућа задружна) ${ }^{117}$ настала, захтевају се три услова: крвно (или грађанско) сродство, заједница имања и заједница живота и рада. ${ }^{118}$

Што се тиче вршења власти унутар задруге, њу врше задружни савет, ${ }^{119}$ старешина и старешица. Старешина је, по правилу, најстарији члан задруге, а има, пре свега, управну власт, односно сви његови управни акти (нпр. распоређивање задружних послова) су пуноважни и обавезују задругу, али је и старатељ малолетних и пословно неспособних задругара. ${ }^{120}$ Иако оваква позиција старешине подсећа на patria potestas, разлике су велике, јер је старешина породице само први међу једнакима, те не може да разбаштини синове или да самостално располаже породичним имањем, а остали задругари имају право да се жале уколико је предузета нека од ових радњи. ${ }^{121}$ Старешица је једина жена која има одређену власт у задрузи, која додуше није правна, већ фактичка власт над женским особљем у задрузи. ${ }^{122}$

стојања овог института, сматрамо да не треба исцрпно говорити о положају жене у породичној задрузи, већ само у основним цртама.

115 То је још једна разлика између СГЗ-а и АBGB. Вид. S. Avramović, „The Serbian Civil Code", 441 и даље.

116 Никола Ф. Павковић, „Породична задруга у Српском грађанском законику”,

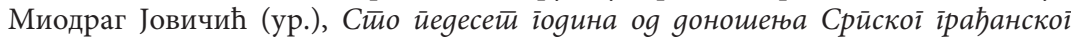
законика (1844-1994), Зборник раgова са научної скуйа одржаної 23. и 24. маја 1994, 1996, 329. Додуше, било је више указа о забрани поделе задруга, почев од Првог српског устанка до 1839.

117 Од времена Вука Караџића се користи термин задруга. 3. Мирковић, Срйска ирравна истиорија, 150.

$118 \$ 57$. СГЗ-а: „Под задругом или задружном кућом разумева се више лица пунолетних, самих или са својим потомством у заједнини живећих. Они су у одношају међусобном задружни. Где таква заједнинскога живота нема, зову се инокосни.” \$ 507. СГЗ-а: „Задруга је онде, где је смеса заједничког живота и имања свезом сродства или усвојењем по природи основана и утврђена. Задруга зове се и кућа или кућа задружна за разлику од инокосне." Вид. Н. Павковић, 330; 3. Мирковић, Срйска йравна истиорија, 150.

119 Задружни савет се састоји од свих пунолетних задругара, односно од малолетних уколико су ожењени или еманциповани. Био је надлежан за све послове располагања, односно друге послове који су излазили ван оквира власти старешине. 3. Мирковић, Срйска йравна истиорија, 151.

120 Ibid.

121 Ibid; Н. Павковић, 333.

122 3. Мирковић, Срйска йравна исӣорија, 151. 
Што се тиче других женских особа, оне се не сматрају задругарима, јер би било противно народним обичајима да жена и мушкарац буду у једнаком положају. Жене су дужне да се баве ситним пословима, женским пословима као што је кухињски рад, спремање хране за мушкарце како би они могли да одржавају задругу. „Жене нису стубови задруге, већ су оне један од чинилаца које те стубове помажу. Зато се оне не могу ни равнати са тим стубовима", већ оне имају само право на издржавање, да се удају и да буду одбрањене од лица која нису у задрузи. ${ }^{123}$ у случају преудаје, оне задржавају свој мираз. ${ }^{124}$

Након смрти мужа, жена остаје у задрузи и припада јој право уживања на делу свог мужа у задрузи, мада је и она свакако дужна „припомагати”. ${ }^{125}$ Перић говори да њој свакако није ни потребан удео у заоставштини, јер ће њу издржавати задруга у којој се налази док се не уда, а кад се уда онда ће је издржавати муж. ${ }^{126}$ Слично као и у инокосним породицама, и овде ћерка може да наследи само уколико њен умрли отац у задрузи не остави иза себе мушку децу. ${ }^{127}$ Тада се најмлађој сестри доводи муж у кућу. ${ }^{128}$

Чињеница постојања задруге у СГЗ-у, односно непостојања исте у ИГЗ-у указује на разлику у друштвеном контексту између тадашње Србије и Италије. У поређењу са италијанским, српско је више друштво сељака, уз мали проценат градског становништва, те некретнине представљају битан извора стицања. Због тога, законик ограничава могућност да се имање смањује услед наслеђивања, јер се и сама задруга тешко одриче земље. Облици сеоске породице који су слични задругама се могу пронаћи и у земљорадничким деловима Италије, ${ }^{129}$ али они нису споменути у законику јер сељаштво није утицало на писање ИГЗ-а.

123 Ж. Перић, Заяружно ирраво ӣо Грађанском законику Кратевине Србије, Део први, Београд 1924, 29.

124 Вид. \$ 524. СГЗ-а. Интересантно је навести решење из нацрта будућег српског грађанског законика, сачињеног на основу ФГЗ-а - у случају развода брака женином кривицом, муж задржава цео мираз изузев једног пара хаљина. Вид. Гордана Дракић, Урош Станковић, „Нови подаци о првим покушајима кодификације грађанског права у Кнежевини Србији”, Зборник раgова Правног̄ факул-

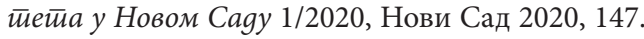

125 \$23. СГЗ-а. Према законодавном тумачењу од 28. јула 1849. Бр. 1147, прецизирано је да жена свакако нема право да наследи свог умрлог мужа, већ само да ужива његов део до смрти, односно преудаје. Вид. друга тумачења и одлуке различитих судова о овој норми у: И. Петковић, 226.

126 Ж. Перић, Заяружно ирраво, 29-30.

$127 \$ 529$. СГЗ-а.

128 Н. Павковић, 333.

129 О земљорадницима вид. нпр. Lucy Riall, „Il sud e i conflitti sociali”, Giovanni Sabbatucci e Vittorio Vidotto (eds), L'Unificazione nazionale, 2011, 129 и даље. 


\section{4. ЗАКЉУЧАК}

Када се размотре све анализиране одредбе, може се поставити следеће питање: у ком законику је положај жене у браку и наслеђивању био бољи?

При анализи законика се могу наћи решења која су слична, као што су пословна способност жене у браку, односи родитеља и односи родитеља са децом, и уопште већина анализираних норми.

Ипак, има и случајева када један законик регулише различита питања у односу на други. То је случај са нормама које регулишу склапање брака. Наиме, док се у италијанском законику исцрпно регулише утицај брака на држављанство, српски забрањује брак са нехришћанином. Такође, то је случај и са нормама о задрузи у СГЗ-у, док у ИГЗ-у задруга не постоји. Не сматрамо да је једно решење боље од другог, већ ова чињеница само указује на то да се питање положаја жене, као што је већ напоменуто, мора посматрати у складу са другим околностима у одређеној држави у одређеном периоду. Ове разлике посебно указују и на чињеницу да је друштво у посматраним државама конципирано на различит начин, односно да се у СГЗ-у може приметити много већи утицај сељака у односу на ИГЗ.

Примећује се већи број мањих разлика у нормама (нпр. без пристанка родитеља се према ИГЗ-у може склопити брак тек након навршења двадесет пете године за мушкарце, а двадесет прве за жене, односно осамнаесте за оба пола према СГЗ-у). Међутим, чини нам се да се већина разлика може занемарити, јер су већим делом незнатне.

Чини нам се да је правилно закључити да постоје две анализиране категорије норми које су на безусловно бољи начин регулисане у једном законику. То је случај, пре свега, са законским наслеђивањем. Наиме, док је у ИГЗ-у признато једнако право наслеђивања мушкој и женској брачној деци, СГЗ прави велику полну дискриминацију. 3бог тога нам се чини да је најбоље закључити да су норме у вези са законским наслеђивањем боље прописане у ИГЗ-у. Са друге стране, треба посматрати и чињеницу да је ИГЗ донет двадесет једну годину након СГЗ-а, што указује на чињеницу да је оправдано очекивати и неке норме које су, према нашем мишљењу, боље у односу на српски. Међутим, СГЗ код развода брака код прељубе не прецизира да је могућ само због женине прељубе, што је свакако боље решење у односу на италијанско које врши полну дискриминацију у случају тражења сепарације.

Коначно, последња велика разлика међу законицима за коју сматрамо да завређује посебан помен јесте чињеница да положај 
жене у породичној заједници у СГЗ-у није регулисан једнообразно, док свакако то јесте случај са ИГЗ-ом. Наиме, у зависности од тога да ли се жена налази у задружној породици или не, њен положај се мења. Сматрамо да она ужива више права ван задруге, јер је у њој свака жена потпуно обесправљена, осим старешице, која додуше врши само фактичку власт над другим женама. Са друге стране, породична заједница која није задружна омогућава жени ипак стицање неких права, иако су она веома ограничена. Примера ради, она може стећи имовину у виду поклоњене ствари уколико добије сагласност мужа, што свакако не може у задрузи јер се не сматра чланом исте. Са друге стране, ИГЗ садржи једнообразно решење у погледу регулисања породичних односа жене у браку, јер задруга није позната овом законику.

Као што је то врло често случај, чини нам се да је тешко одговорити да је један законик неспорно бољи од другог. Сматрамо да законици регулишу централно питање рада на релативно сличан начин и да они одговарају духу свог времена, што наравно не значи да су напредни у погледу теме положаја жене.

\section{БИБЛИОГРАФИЈА}

\section{ИЗВОРИ:}

Закон о наслеђивању - Сл. іласник РС, бр. 46/95, 101/2003 - одлука УСРС и $6 / 2015$;

Codice civile del Regno d'Italia, Stamperia Reale, Torino 1865 (доступно на https://www.notaio-busani.it/it-IT/codice-civile-1865.aspx, приступљено 18. априла 2020);

Felice Voltolina, Commento al codice civile del regno d'Italia 25 giugno 1865 colle relative leggi romane, colle opinioni e dottrine de piu celebri scrittori di diritto e di legislazione, colle indicazioni delle leggi napoleoniche ed austriache nonche delle patrie sparse in altri codici Felice Voltolina, Tipografia Municipale di Gaetano Longo, Venezia 1873;

Лазар Марковић (прир.), Грађански законик Краљевине Србије са крайким објаштьенима, Друго издање, Издавачка књижара Геце Кона, Београд 1921;

Димитрије Матић (прир.), Објаснене Грађанскої законика за Кюажестиво срйско 2/1, Београд 1851.

Иван Д. Петковић (прир.), Грађански законик за Кралевину Србију - Објашъен овлукама Касаиионої суgа у Беоіраgу, Београд 1939. 


\section{ЛИТЕРАТУРА:}

Fente successorale: qu'est-ce que c'est?, https://www.capital.fr/votre-argent/fente-successorale-1343470, приступљено 30. октобра 2020;

Сима Аврамовић, „Српски грађански законик (1844) и правни транспланти - копија аустријског узора или више од тога?”, Милена Полојац, Зоран С. Мирковић, Марко Ђурђевић, (ур.), Срӣски ірађански законик - 170 іолина, Правни факултет Универзитета у Београду Центар за издаваштво и информисање 2014, 13-46;

Sima Avramović, „The Serbian Civil Code of 1844: A Battleground of Legal Traditions", Thomas Simon, Gerd Bender und Jani Kirov (Hrsg.), Konflikt und Koexistenz Die Rechtsordnungen Südosteuropas im 19. und 20. Jahrhundert, Band II: Serbien, Bosnien-Herzegowina, Albanien, 2017, 380-482;

Marzio Barbagli, David I. Kertzer, Storia della famiglia italiana, 1750-1950, Il Mulino, Bologna 1992;

Ана Божић, Положај жене у йриваитном ӣраву: кроз истиорију gо gанас, Београд 1939;

Elise Boulding, The Underside of History: A View of Women Through Time, Westview Press, Boulder 1977;

Angiolo Burri, Dei diritti delle donne secondo il Codice Civile del Regno d'Italia, Tip. Salani, Firenze 1869;

Giulia Galeotti, „L'autorizzazione maritale nel primo codice civile unitario: un istituto „estraneo” alla tradizione italiana?”, Dimensioni e problemi della ricerca storica 2/2005, 155-182;

W. D’Avanzo, „Successione”, Enciclopedia Italiana - II Appendice, XXXII, Treccani, 1949, 923 (доступно на: Successione, http://www.treccani.it/enciclopedial successione_res-f38e76cd-87e6-11dc-8e9d-0016357eee51_\%28Enciclopedia-Italiana\%29/, приступљено 26. априла 2020);

Наташа Делић, „Кривично дело насиља у породици (члан 194. КЗС): законски појам, доктринарни ставови и судска пракса", Лепосава Крон (ур.), Насилнички криминал: етииолоіија, феноменолоїија, ирревениија, 2010, 91-110;

Гордана Дракић, Урош Станковић, „Нови подаци о првим покушајима кодификације грађанског права у Кнежевини Србији”, Зборник раgова Правноі факулиетей у Новом Саgу 1/2020, 141-157;

Марија Драшкић, „Усвојење и хранитељство - добра традиција српског грађанског законика?”, Милена Полојац, Зоран С. Мирковић, Марко Ђурђевић (ур.), Срйски ірађански законик - 170 іолина, 2014, 127-144;

Марија Драшкић, Порояччно ирраво и йрава gетиейа, Правни факултет Универзитета у Београду, Београд 2015;

Joshua Eastin, „Aseem Prakash, Economic Development and Gender Equality: Is There a Gender Kuznets Curve?", World Politics 65(1), 2013, 156-186; 
Eligio Imarisio, Donna poi artista: identità e presenza tra Otto e Novecento, FrancoAngeli, Milano 1996;

Милош М. Јовичић, Правни овноси у йородици, Лични оgноси међу суйружниичма. Родийељско йраво, Београд 1935;

Андреја Катанчевић, „Трошкови порођаја и Српски грађански законик”, Милена Полојац, Зоран С. Мирковић, Марко Ђурђевић (ур.), Срйски ірађански законик - 170 іооина, 2014, 343-352;

Stefania Licini, „Donne e ricchezza: suggerimenti da una fonte fiscale (Milano, 1862-1900)", Working papers at the Hyman P. Minsky Dep. of Economic Studies - Quaderni del Dip. di Scienze economiche Hyman P. Minsky, 2004 (доступно на: Donne e ricchezza: suggerimenti da una fonte fiscale (Milano, 1862-1900), https://www.researchgate.net/publication/4998580_Donne_e_ricchezza_suggerimenti_da_una_fonte_fiscale_Milano_1862-1900, приступљено 10. септембра 2020);

Stefania Licini, „Women, wealth and finance (19th century Italy)”, Working papers at the Hyman P. Minsky Dep. of Economic Studies - Quaderni del Dip. di Scienze economiche Hyman P. Minsky, 2006 (доступно на: Women, wealth and finance. (19th century Italy), https://www.researchgate.net/ publication/4923924_Women_wealth_and_finance19th_century_Italy, приступљено 13. септембра 2020);

Лазар Марковић, Наслеgно ӣраво, Београд 1930;

Laura Marchesano, „Alla ricerca di una moglie. Celibato rurale e migrazioni matrimoniali", Storicamente 6 nr. articolo 5, 2010 (доступно на: Laura Marchesano, Alla ricerca di una moglie. Celibato rurale e migrazioni matrimoniali, https://storicamente.org/marchesano_immigrazione_matrimoniale, приступљено 11. октобра 2020);

Зоран С. Мирковић, „Уводна правила и увођење у живот Српског грађанског законика", Милена Полојац, Зоран С. Мирковић, Марко Ђурђевић (ур.), Срӣски ірађански законик - 170 іоgина, 2014, 75-104;

Зоран С. Мирковић, Срйска йравна исйорија, Правни факултет Универзитета у Београду, Београд 2017;

Милован М. Митровић, Данило С. Вуковић, Основи соииолоїчје йрава, Правни факултет Универзитета у Београду, Београд 2018;

Митра Митровић, Положај жене у савременом светиy, Народна књига, Београд 1960;

Anna Maria Mozzoni, La donna in faccia al progetto del nuovo codice civile italiano, Tipografia sociale, Milano 1865;

Carroll Moulton, Ancient Greece and Rome: An Encyclopedia for Students (4 Volume Set), Scribner, New York 1998 (доступно на: Ancient History \& Civilisation, MARRIAGE AND DIVORCE, https://erenow.net/ancient/ ancient-greece-and-rome-an-encyclopedia-for-students-4-volume-set/274. php, приступљено 13. октобра 2020); 
Никола Ф. Павковић, „Породична задруга у Српском грађанском закони-

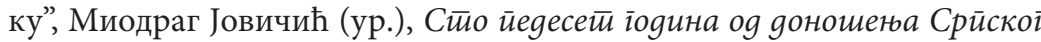
ірађанскої законика (1844-1994), Зборник раgова са научної скуйа оgржаної 23. и 24. маја 1994, 1996, 329-336;

Марко Павловић, „Положај жене по српском грађанском законику”, Миод-

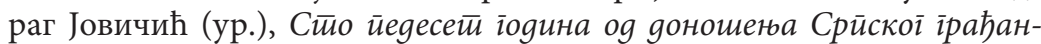
скої законика (1844-1994), Зборник раgова са научної скуйа оgржаноі̄ 23. и 24. маја 1994, 1996, 207-218;

Germano Palmieri, Dizionario dei termini giuridici, Nuova edizione ampliata e aggiornata, Biblioteca Universale Rizzoli, Milano 2006;

Raffaella Pasquili, „La famiglia nel tempo”, Silvana Serafin, Marina Brollo (ed.), Donne, politica e istituzioni: il tempo delle donne, 2013, 221-233;

Loredana Garlati, „La famiglia tra passato e presente”, Salvatore Patti, Maria Giovanna Cubeddu (ed.), Diritto della famiglia, 2011, 1-48;

Живојин Перић, Заgружно йраво йо Грађанском законику Кральевине Србије, Део први, Београд 1924;

Живојин Перић, Лично брачно йраво ӣo Срйском ірађанском законику, Библиотека за правне и друштвене науке, Београд 1934;

Сретен Л. Поповић, Пуйоване ӣо новој Србији 1878. и 1880, Београд 1950;

Kenneth Reid, Marius Johannes De Waal, Reinhard Zimmermann, Comparative Succession Law, Intestate Succession, Oxford University Press, Oxford 2015;

Lucy Riall, „Il sud e i conflitti sociali”, Giovanni Sabbatucci e Vittorio Vidotto (eds), L'Unificazione nazionale, 2011, 129-149;

Bonnie G. Smith, The Oxford Encyclopedia of Women in World History, Volume 1, Oxford University Press, London 2008;

Војислав Станимировић, „Снага обичаја - породица у српском грађанском законику између старог и новог”, Милена Полојац, Зоран С. Мирковић, Марко Ђурђевић (ур.), Срйски ірађански законик - 170 іодина, 2014, 145-166;

Урош Станковић, „Хиљаду осамсто четрдесет шеста - наследноправни положај женске деце по трећи пут на дневном реду”, Срӣски ірађански законик - 170 іоgина, Милена Полојац, Зоран С. Мирковић, Марко Ђурђевић (ур.), 2014, 407-416;

Миленко С. Филиповић, Таково, Београд 1960;

Eva Cantarella, L’ambiguo malanno: condizione e immagine della donna nell'antichità greca e romana, Feltrinelli Editore, Milano 2010;

Linda L. Clark, Linda Loeb Clark, Women and Achievement in Nineteenth-Century Europe, Cambridge University Press, Cambridge 2008;

Фердо Чулиновић, Жена у нашем кривичном ирраву, Глобус, Београд 1934. 


\title{
Andrej CONFALONIERI ${ }^{*}$
}

\section{COMPARISON OF THE LEGAL POSITION OF WOMEN \\ IN MARRIAGE AND SUCCESSION IN THE SERBIAN \\ CIVIL CODE OF 1844 AND THE CIVIL CODE \\ OF THE KINGDOM OF ITALY OF 1865}

\begin{abstract}
Summary
This paper deals with a comparative analysis of the legal position of women in the Serbian (1844, hereinafter SCC) and Italian (1865, hereinafter ICC) Civil Codes, considering the norms that regulate the position of women in marriage and those regarding inheritance. Confronting these two codes is relevant for various reasons. Firstly, it has not been done before in Serbian jurisprudence. Secondly, although based on different models (the Italian on the French Code, the Serbian on the Austrian Code, hereinafter ACC), each of them differs in some aspects from their model in the law of marriage and inheritance. Thirdly, it's important from a historical aspect, because the Italian Kingdom had just been formed and the Serbians had relieved themselves of the centuries-long Turkish government, so there's a similarity in the process of writing the codes. Although the writing styles of the codes are unalike, there are certain similarities in the provisions on marriage, the relationship between spouses, the relationship between spouses and children, and in terms of testamentary succession. For example, both codes give more rights to the husband (being the "head of the family"), and while the wife can write a will, she is not allowed to be a legal witness to another person's will. There are several differences between the two codes, but most of them are negligible. For instance, both codes prescribe a parent's permission for marriage, while the marriageable age that doesn't require consent differs (i the ICC 25 years old for men and 21 for women, whereas in Serbia it's 18 years old for both men and women). However, a few differences are relevant. The biggest one is the way in which intestate succession is regulated: the right to inherit is recognized to legitimate children regardless of gender in the Italian code, while in the Serbian code women are excluded from inheritance, which is one of the major differences between the SCC and ACC. In fact, when writing the code, Hadžić didn't want this provision incorporated in the law, but it was added nevertheless. The second biggest difference between the ICC and the SCC consists in the fact that adultery is considered a reason for legal separation (and not divorce, because divorce was not allowed) in the ICC only if it is committed by the wife, while in the Serbian one the sex of the adulterer is not specified and can lead to divorce even if it's done by the husband. Finally, the Serbian legislator

* The author is a third-year student at the University of Belgrade Faculty of Law, andrej.confalonieri@gmail.com
\end{abstract}


also regulates the position of women in the „zadruga” (a type of joint family), in which women cannot be members, nor can they inherit, while that institute is not prescribed in the Italian one.

Key words: Legal position of women. - Serbian Civil Code. - Civil Code of the Kingdom of Italy. - Marriage. - Intestate succession.

Рад приспео / Paper received: 22.10.2020.

Прихваћен за објављивање / Accepted for publication: 29.12.2020. 